\title{
Chemical residuality in maize (Zea mays L.) fields irrigated with deep well water
}

\section{Residualidad química en campos de maíz (Zea mays L.) irrigados con agua de pozo profundo}

\author{
Ma. Elizabeth Azpilcueta-Pérez ${ }^{1}$, Aurelio Pedroza-Sandoval ${ }^{2 *}$, Ricardo Trejo-Calzada ${ }^{2}$, Ignacio \\ Sánchez-Cohen ${ }^{3}$ y María del Rosario Jacobo-Salcedo ${ }^{3}$ \\ ${ }^{1}$ Estudiante de la Maestría en Recursos Naturales y Medio Ambiente en Zonas Áridas, Universidad Autónoma Chapingo \\ (UACh). Km. 38 Carretera Gómez Palacio-Chihuahua, CP. 35230. Bermejillo, Durango, México. \\ ${ }^{2}$ Unidad Regional Universitaria de Zonas Áridas, UACh. Km. 38 Carretera Gómez Palacio-Chihuahua, CP. 35230. Bermejillo, \\ Durango, México. \\ ${ }^{3}$ Centro Nacional de Investigación Disciplinaria en Relaciones Agua Suelo Planta Atmosfera del INIFAP. Km. 6.5 margen \\ derecha canal Sacramento, CP. 35140. Gómez Palacio, Durango, México. \\ ${ }^{*}$ Corresponding author: apedroza@chapingo.uruza.edu.mx
}

Scientific note received: December 5, 2016 accepted: August 3, 2017

\begin{abstract}
The aim was to conduct a residual analysis of the main cationic elements, heavy metals and arsenic in irrigated maize fodder production. Four soil and maize plant samplings were conducted in eight sites in April, May, June and July, 2014. Ca, Na, As, and Pb concentrations were higher in the soil. The As concentration was higher in June and July. La Purísima had a higher As concentration, while Bermejillo, La Galicia and La Rosita had a higher $\mathrm{Ca}$ concentration. $\mathrm{K}, \mathrm{Ca}, \mathrm{Pb}$ and $\mathrm{Zn}$ had higher concentrations in the maize plant, with $\mathrm{Ca}, \mathrm{Na}$ and $\mathrm{K}$ having higher values in July and $\mathrm{Mg}, \mathrm{Pb}$ and $\mathrm{Zn}$ being higher in May and July. The content of $\mathrm{Ca}, \mathrm{Mg}, \mathrm{Na}$ and $\mathrm{K}$ did not differ among regions; arsenic was higher in Leon Guzmán and La Rosita.
\end{abstract}

Key words: Salinity, environment contamination, chemical contamination, toxicity, contaminated water

RESUMEN. El objetivo fue hacer un análisis residual de los principales elementos en áreas irrigadas productoras de forraje. Se realizaron cuatro muestreos de suelo y planta de maíz en ocho localidades en los meses de abril, mayo, junio y julio de 2014. El Ca, $\mathrm{Na}$, As y Pb tuvieron mayor concentración en el suelo, el As tuvo mayor concentración en junio y julio. La Purísima tuvo mayor concentración de As, mientras que Bermejillo, la Gallega y la Rosita tuvieron mayor concentración de $\mathrm{Ca}$. El K, Ca, $\mathrm{Pb}$ y $\mathrm{Zn}$ estuvieron presentes en mayor concentración en la planta de maíz, presentando el $\mathrm{Ca}$, $\mathrm{Na}$ y $\mathrm{K}$ los mayores valores en julio y el $\mathrm{Mg}, \mathrm{Pb}$ y $\mathrm{Zn}$ en mayo y julio. El contenido de $\mathrm{Ca}, \mathrm{Mg}, \mathrm{Na}$ y K, no varió entre regiones; y el arsénico fue mayor en León Guzmán y la Rosita.

Palabras clave: Salinidad, contaminación ambiental, contaminación química, toxicidad, agua contaminada

\section{INTRODUCTION}

Agriculture accounts for approximately $77 \%$ of water use in Mexico, followed by the public water supply system with $14 \%$, electrical energy generation with 5\% and industry with 4\% (CNA 2011). The quality of water for agricultural use and its availability is a topical issue from the social, productive and environmental point of view (Ayers and Wescott 1987). Water pollution and scarcity has a severe impact on ecosystems and the survival of organisms (Galadima et al. 2011). Therefore, the frequency and intensity of droughts in arid areas is increasing, resulting in intensive use of deep well water in northern Mexico's irrigation districts (CNA 2015).

The Comarca Lagunera covers an area of 220 thousand ha, with a maximum irrigable area of 105 thousand ha (García et al. 2006), most of which is dedicated to fodder production. Alfalfa, maize 
and sorghum are the main fodder crops (Pedroza et al. 2014). Water is a scarce resource in the Comarca Lagunera due to recurrent droughts and increased groundwater extraction, which generates overexploitation of aquifers by more than $480 \mathrm{hm}^{3}$ (García et al. 2006). Water extracted from wells at more than $200 \mathrm{~m}$ deep contains nutrients and pollutants (Sardiñas et al. 2006), mainly in places where wastewater has been used in agricultural crops, with reports of an upward trend in heavy metal concentrations with a consequent impact on health and the environment (Mancilla et al. 2012). Overexploitation of the aquifer has resulted in the extraction of poor quality groundwater, with a number of negative effects on the environment and health, such as: soil sodicity and salinization that make soils infertile and unproductive; damage due to the clogging of pressurized irrigation systems; plant toxicity damage; arsenic and heavy metal residuals for a high risk to animals and humans (Bonet et al. 2011).

The quality of water for agricultural use is a function of the quantity and type of salts it contains (Sarabia et al. 2011). The high concentration of salts in irrigation water reduces water availability for plants, which means that greater effort is exerted to absorb water, which causes physiological stress due to dehydration and affects their growth and development (Pérez-León 2011). Therefore, the aim of this study was to make a residual soil and plant evaluation of fields dedicated to the cultivation of fodder maize irrigated with deep well water, as indicators of risk to health and the environment.

\section{MATERIALS AND METHODS}

\section{Geographic location of the area}

The study was conducted in the Lagunera Region of the States of Coahuila and Durango, Mexico, which is located at $24^{\circ} 22^{\prime} \mathrm{NL}$ and $102^{\circ}$ 22' WL at 1120 masl (García de Miranda 1973). Geopolitically, the area corresponded to the municipalities of San Pedro de las Colonias, Gómez Palacio, Lerdo, Bermejillo and Tlahualilo. The first belongs to the State of Coahuila and the others to the State of Durango, Mexico.

\section{Soil and plant sampling}

According to the historical chemical water pollution database provided by the National Water Commission (CNA for its initials in Spanish), and by using digitized maps and Geographic Information System (GIS) tools, the area of influence of the present study was delineated. Wells (sites) that contained consistent information on water quality were identified, being those with identification number 2576, 2612, 1103, 1125, 1200, 3387, 950 and 760 (Figure 1) in the sites of La Loma, León Guzmán, La Gallega, Bermejillo, La Jarita, Venecia, La Rosita and La Purísima, respectively, which are representative of the Comarca Lagunera irrigation region.

Soil sampling was carried out from April to July 2014 in a one-hectare area planted with fodder maize and irrigated with water from each deep well. For the extraction of the sample, a Van Walt (USA) Riverside soil auger was used. The samples were extracted in accordance with standard NMXAA-132-SCFI-2006 (SCFI 2006). Simple random sampling by means of a diamond-shaped path was used, taking five soil samples at a depth of 20 to $30 \mathrm{~cm}$, and then mixing them to obtain a $1 \mathrm{~kg}$ composite sample. Each sample was packed and labelled in a polyethylene bag for transfer to the laboratory. The sampling of the plant material from May to July 2014 was done by taking one plant per soil sample extraction site. The samples were washed with distilled water and $5 \% \mathrm{HNO}_{3}$, dried in an oven for $24 \mathrm{~h}$ and then crushed, packed and labeled in a polyethylene bag.

\section{Chemical analysis}

The chemical analysis of plant and soil was carried out based on NOM-117-SSA1-1994 (SS 1994), which sets out the test method for the determination of $\mathrm{As}, \mathrm{Cd}, \mathrm{Pb}$ and $\mathrm{Zn}$. Soil samples were weighed and ground, taking $0.5 \mathrm{~g}$ of sample, to which $10 \mathrm{ml}$ of ultrapure concentrated nitric acid were added and the digestion of the samples was started in an automated MARSXpress digester (CEM USA). Subsequently, $40 \mathrm{ml}$ of distilled wa- 


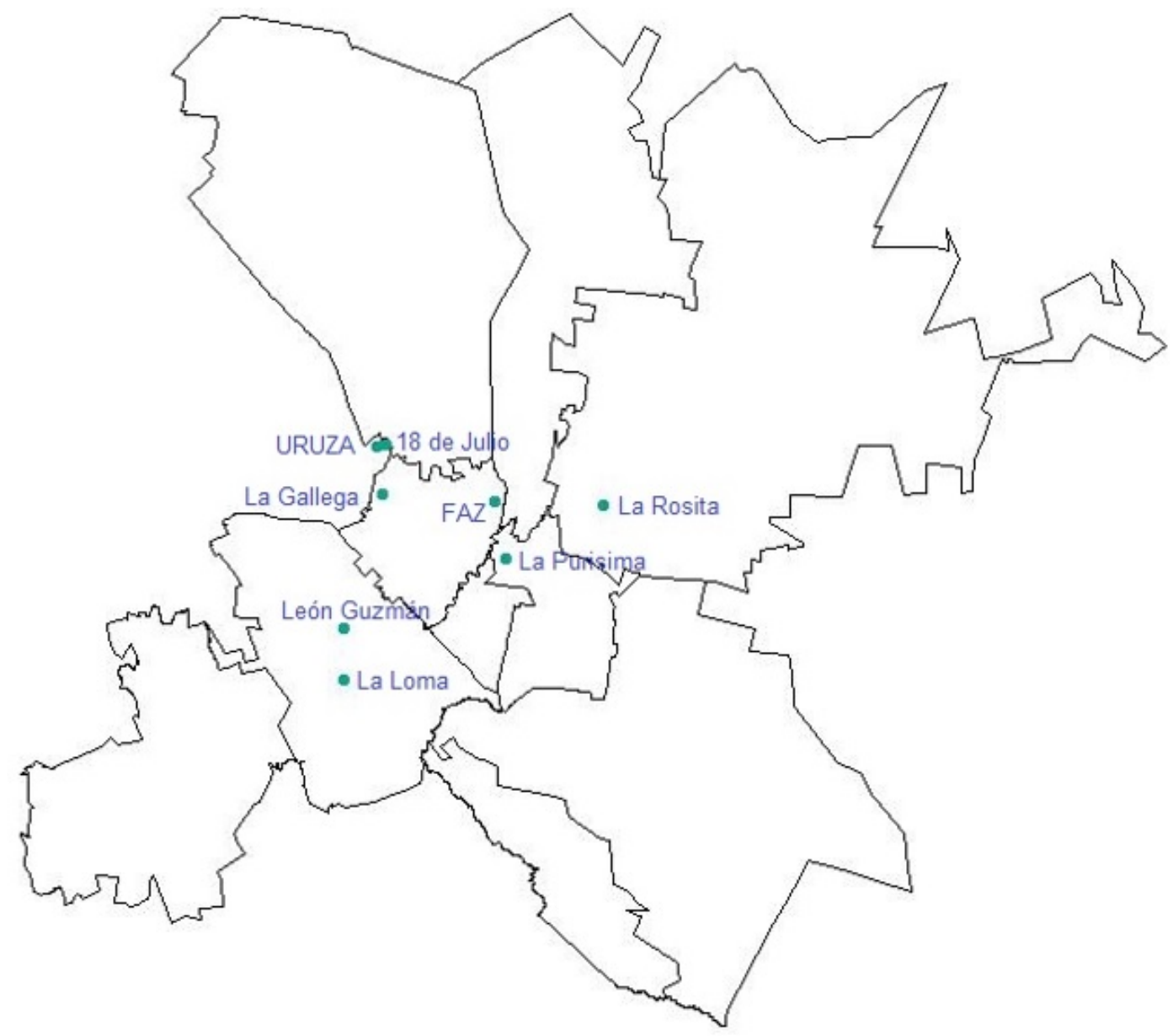

Figure 1. Map of the sites where the main monitored wells are located for the current analysis of water for agricultural use.

ter were added and the sample was filtered, after which it was kept under dark conditions until analysis. The determinations of cationic elements, heavy metals and arsenic were made with the Perkin Elmer Company (USA) Analyst Model 700 Atomic Absorption Spectrophotometer, using the graphite furnace method.

\section{Measured variables}

The variables measured in soil and plant were at the concentrations of cationic elements $\mathrm{Ca}, \mathrm{Mg}$, $\mathrm{Na}$ and $\mathrm{K}$ in meq $\mathrm{L}^{-1}$ and arsenic (As) and heavy elements $\mathrm{Cd}, \mathrm{Pb}$ and $\mathrm{Zn}$ in $\mathrm{mg} \mathrm{kg}^{-1}$.

\section{Statistical analysis}

An analysis of variance and Tukey's range test was performed using SAS V.9.0 software, taking as replicates the sampling sites (8) for the case of the temporal analysis, while for the spatial analysis the replicates corresponded to the sampling dates.

\section{RESULTS AND DISCUSSION}

The quality of the water for agricultural use is a function of physico-chemical characteristics, such as the concentration of dissolved salts (EC), relative presence of sodium (SAR), content of carbonates and bicarbonates that condition the $\mathrm{pH}$ and the concentration of different cationic elements and heavy 


\begin{tabular}{|c|c|c|c|c|c|c|c|c|}
\hline Month & $\mathrm{Ca}$ & $\mathrm{Mg}$ & $\mathrm{Na}$ & $\mathrm{K}$ & As & $\mathrm{Cd}$ & $\mathrm{Pb}$ & $\mathrm{Zn}$ \\
\hline April & $15.62^{a}$ & $5.54^{a}$ & $16.05^{a}$ & $1.17^{a}$ & $31.50^{b}$ & $4.21^{a}$ & $41.36^{a}$ & $2.62^{a}$ \\
\hline May & $13.75^{a}$ & $5.42^{a}$ & $15.16^{a}$ & $0.86^{a}$ & $43.28^{a b}$ & $6.87^{a}$ & $43.76^{a}$ & $1.45^{a}$ \\
\hline June & $17.91^{a}$ & $6.05^{a}$ & $20.56^{a}$ & $0.87^{a}$ & $48.50^{a}$ & $6.39^{a}$ & $46.55^{a}$ & $1.29^{a}$ \\
\hline July & $15.97^{a}$ & $5.35^{a}$ & $10.73^{a}$ & $0.81^{a}$ & $49.25^{a}$ & $4.21^{a}$ & $47.03^{a}$ & $1.91^{a}$ \\
\hline
\end{tabular}

metals (Castellón et al. 2015). It was found that the As concentration in the soil is above the limit allowed by NOM-147-SEMARNAT-2004, which establishes a maximum value of $22 \mathrm{mg} \mathrm{kg}^{-1}$ in agricultural soil (SEMARNAT 2007). This level represents a current and potential risk due to its permanent disposition, and also because it can accumulate in the plant; for example, from maize fodder, it can pass directly to fatty tissues and animal milk. The absorption of As from contaminated water has been reported for hydroponically-grown Lactuca sativa L. (Hüvely et al. 2011).

Of the four cationic elements analyzed in the soil for agricultural use, it was found that $\mathrm{Ca}$ and $\mathrm{Na}$ were at higher concentration levels, with average values of 15.81 and 15.63 meq $L^{-1}$, respectively, whereas $\mathrm{Mg}$ and $\mathrm{K}$ had values of 5.59 and 0.92 meq $L^{-1}$, respectively. As and $\mathrm{Pb}$ were found at higher concentration, with values of 43.13 and 44.68 $\mathrm{mg} \mathrm{kg}{ }^{-1}$, whereas $\mathrm{Cd}$ and $\mathrm{Zn}$ recorded concentrations of 5.42 and $1.28 \mathrm{mg} \mathrm{kg}^{-1}$, respectively. The behavior without change over time of the cations of $\mathrm{Ca}, \mathrm{Mg}, \mathrm{Na}$ and $\mathrm{K}$, as well as of the metals $\mathrm{Cd}$, $\mathrm{Pb}$ and $\mathrm{Zn}$, means that the concentrations remain stable but high from April to June, a period of time in the region when maize fields are irrigated with poor quality deep well water (Azpilcueta-Pérez et al. 2017). The above is environmentally relevant, especially in the case of heavy metals, given that they are persistent environmental pollutants, with a minimum density five times that of water, so they cannot be metabolized by organisms, with severe toxicity consequences (Ehi-Eromosele and Okiei 2012).

The cations of $\mathrm{Ca}, \mathrm{Mg}, \mathrm{Na}$ and $\mathrm{K}$ did not show temporal variation $(p \leq 0.05)$ in the analyzed months of 2014. By contrast, As had significant variation, with a higher concentration in the months of June and July ( 49.25 and $48.5 \mathrm{mg} \mathrm{kg}^{-1}$ ), whereas the lowest concentration was recorded in April (31.5 $\mathrm{mg} \mathrm{kg}{ }^{-1}$ ). Regarding $\mathrm{Cd}, \mathrm{Pb}$, and $\mathrm{Zn}$, no variation was found (Table 1). The Bermejillo, La Gallega and La Rosita sites stand out with Ca concentrations in the soil of 20.36, 24.24 and 23.09 meq $\mathrm{L}^{-1}$, respectively, while the rest of the sites had similar values, with the exception of La Loma, which had a concentration of 5.64 meq $\mathrm{L}^{-1}(\mathrm{p} \leq 0.05)$. For $\mathrm{Mg}, \mathrm{Na}$ and $\mathrm{K}$ there is similar variation among sites; La Gallega stands out with the highest $\mathrm{Mg}$ values (10.13 meq $\left.\mathrm{L}^{-1}\right)$, whereas Bermejillo and La Rosita had high Na concentrations. The rest of the sites had significantly lower values of these elements. In relation to $\mathrm{K}$, the Bermejillo region has a concentration of 1.85 meq $\mathrm{L}^{-1}$ (Table 2).

$\mathrm{K}$ and $\mathrm{Ca}$ had higher concentrations, with average values of 1.064 and 0.563 meq $L^{-1}$ in the plant, respectively, whereas $\mathrm{Mg}$ and $\mathrm{Na}$ recorded lower concentrations with values of 0.25 and 0.072 meq $L^{-1}$, respectively. $\mathrm{Pb}$ and $\mathrm{Zn}$ were found with greater concentration in the Comarca Lagunera, with values of 26.86 and $41.58 \mathrm{mg} \mathrm{kg}^{-1}$, whereas As and $\mathrm{Cd}$ were at lower concentrations, with values of 2.22 and $3.4 \mathrm{mg} \mathrm{kg}^{-1}$, respectively. As varied significantly, with La Purísima having the highest concentration (61.58 $\mathrm{mg} \mathrm{kg}^{-1}$ ), whereas the rest of the sites had concentrations between 37.27 and $49.42 \mathrm{mg} \mathrm{kg}^{-1}$, except for Bermejillo, which had the lowest concentration $\left(27.88 \mathrm{mg} \mathrm{kg}^{-1}\right)$. Cd did not vary among sites and $\mathrm{Pb}$ was statistically higher in La Purísima ( $58.95 \mathrm{mg} \mathrm{kg}{ }^{-1}$ ). The concentration of $\mathrm{Zn}$ was greater in La Gallega, La Purísima 
Table 2. Spatial variation of the mean concentration of different cationic elements (meq $\mathrm{L}^{-1}$ ) and heavy elements $\left(\mathrm{mg} \mathrm{kg}^{-1}\right)$ contained in soil for agricultural use irrigated with deep well water.

\begin{tabular}{ccccccccc}
\hline Site & $\mathrm{Ca}$ & $\mathrm{Mg}$ & $\mathrm{Na}$ & $\mathrm{K}$ & $\mathrm{As}$ & $\mathrm{Cd}$ & $\mathrm{Pb}$ & $\mathrm{Zn}$ \\
\hline Bermejillo & $20.36^{a b c}$ & $8.59^{a b}$ & $28.30^{a}$ & $1.85^{a}$ & $27.88^{b}$ & $7.63^{a}$ & $33.83^{d}$ & $1.20^{b c}$ \\
La Purísima & $11.27^{c d}$ & $1.76^{d}$ & $6.92^{b}$ & $0.64^{b}$ & $61.58^{a}$ & $4.75^{a}$ & $58.95^{a}$ & $2.08^{a b c}$ \\
La Gallega & $24.24^{a}$ & $10.13^{a}$ & $17.81^{a b}$ & $1.16^{a b}$ & $37.27^{a b}$ & $4.33^{a}$ & $40.05^{c d}$ & $3.72^{a}$ \\
La Jarita & $12.81^{b c d}$ & $4.3^{c d}$ & $10.28^{b}$ & $0.48^{b}$ & $38.53^{a b}$ & $4.41^{a}$ & $36.79^{d}$ & $1.02^{b c}$ \\
La Loma & $5.64^{d}$ & $3.45^{c d}$ & $9.48^{b}$ & $0.60^{b}$ & $49.42^{a b}$ & $4.85^{a}$ & $48.56^{b}$ & $1.30^{b c}$ \\
León Guzmán & $14.36^{a b c d}$ & $6.50^{b c}$ & $16.20^{a b}$ & $0.96^{a b}$ & $43.35^{a b}$ & $8.53^{a}$ & $49.33^{b}$ & $3.36^{a b}$ \\
La Rosita & $23.09^{a b}$ & $8.27^{a b}$ & $22.86^{a b}$ & $0.62^{b}$ & $38.57^{a b}$ & $4.37^{a}$ & $41.84^{b c d}$ & $0.89^{c}$ \\
Venecia & $14.72^{a b c d}$ & $1.69^{d}$ & $13.18^{a b}$ & $1.09^{a b}$ & $48.47^{a b}$ & $4.5^{a}$ & $48.06^{b c}$ & $0.99^{c}$ \\
\hline
\end{tabular}

Table 3. Temporal variation of the mean concentration of different cationic elements (meq $\mathrm{L}^{-1}$ ) and heavy elements $\left(\mathrm{mg} \mathrm{kg}^{-1}\right)$ contained in fodder maize plants irrigated with deep well water, at three sampling dates.

\begin{tabular}{ccccccccc}
\hline Month & $\mathrm{Ca}$ & $\mathrm{Mg}$ & $\mathrm{Na}$ & $\mathrm{K}$ & $\mathrm{As}$ & $\mathrm{Cd}$ & $\mathrm{Pb}$ & $\mathrm{Zn}$ \\
\hline May & $0.52^{a b}$ & $0.31^{a}$ & $0.06^{a}$ & $0.26^{c}$ & $2.05^{a}$ & $3.56^{a}$ & $24.4^{b}$ & $60.2^{a}$ \\
June & $0.18^{b}$ & $0.13^{b}$ & $0.06^{a}$ & $0.77^{b}$ & $2.24^{a}$ & $3.40^{a}$ & $23.5^{b}$ & $22.5^{c}$ \\
July & $0.98^{a}$ & $0.30^{a}$ & $0.08^{a}$ & $2.16^{a}$ & $2.36^{a}$ & $3.24^{a}$ & $26.6^{a}$ & $42^{b}$ \\
\hline
\end{tabular}

Tukey's range test $(\mathrm{p} \leq 0.05)$. Values with the same letters within the same column are statistically equal.

and León Guzmán, whereas the rest of the sites had lower concentrations (Table 2). In most of the region, a high As concentration was recorded in the soil, above the limit established in standard NOM-147-SEMARNAT-2004 (SEMARNAT 2007), although even in maize plants the concentrations found are above what is allowed (FAO 2009), which implies a risk to health and the environment, due to the high toxicity effect of these elements (Sandeep et al. 2012). The foregoing demands that this problem be addressed through better integrated water management actions in the region, in accordance with what is recommended by national and international organizations (ONU 2012, IMTA 2012), or to carry out some treatment prior to using the water to irrigate crops (Bonilla et al. 2015).
As and $\mathrm{Cd}$ have a residual effect due to their high concentrations in most of the sites studied, without significant variation, which indicates persistence, while $\mathrm{Pb}$ and $\mathrm{Zn}$ varied with a maximum concentration of $60.25 \mathrm{mg} \mathrm{kg}^{-1}$ in May. $\mathrm{Ca}, \mathrm{Mg}$, $\mathrm{Na}$ and $\mathrm{K}$ did not vary among the monitored sites, which indicates that the contents of these elements remained stable during the study period. The concentration of heavy metals in the plant did not vary among sites; As was the only one that had significant spatial variation, which agrees with the spatial variation of this element in the soil. There is a high contamination of cationic elements and heavy metals in soils irrigated with deep well water and in fodder maize plants. $\mathrm{Ca}$, As, and $\mathrm{Pb}$ had the highest concentrations in the soil, while As had the highest concentration in June and July.

\section{LITERATURE CITED}

Ayers RS, Westcott DW (1987) La calidad del agua y su uso en la agricultura. Estudio FAO. Riego y Drenaje 29. Rev. 1. Food and Agriculture Organization. Roma, Italia. 174p.

Azpilcueta-Pérez ME, Pedroza-Sandoval A, Sánchez-Cohen I, Salcedo-Jacobo M del R, Trejo-Calzada R (2017) Calidad química del agua en un área agrícola de maíz forrajero (Zea mays L.) en la Comarca Lagunera, México. Revista Internacional de Contaminación Ambiental 33: 75-83.

Bonet PC, Calzadilla R, Martha P (2011) Calidad del agua de riego y su posible efecto en los rendimientos 
agrícolas en la Empresa de Cultivos Varios Sierra de Cubitas. Revista Ciencias Técnicas Agropecuarias 20: $19-23$.

Bonilla y FMN, Ayala OAI, González CS, Santamaría JJD, Silva GSE (2015) Calidad fisicoquímica del agua del distrito de riego 030 "Valsequillo" para riego agrícola. Revista Iberoamericana de Producción Académica y Gestión Educativa 3: 1-29

Castellón GJJ, Bernal MR, Hernández RMdeL (2015) Calidad del agua para riego en la agricultura protegida en Tlaxcala. Ingeniería 19: 39-50.

CNA (2011) Estadisticas del agua en México, edición 2011. Secretaría del Medio Ambiente y Recursos Naturales. México. 129p.

CNA (2015) Actualización de la disponibilidad media anual de agua en el acuífero Principal-Región Lagunera (0523), Estado Coahuila. Diario Oficial de la Federación, 20 de Abril de 2015. https://www.gob.mx/cms/ uploads/attachment/file/.../DR_0523.pdf. Date consulted: October 5, 2015.

Ehi-Eromosele C, Okiei W (2012) Heavy metal assessment of ground, surface and tap water samples in Lagos Metropolis using anodic stripping voltammetry. Resources and Environment 2: 82-86.

FAO (2009) Norma general del codex para los contaminantes y las toxinas presentes en los alimentos y piensos. CODEX STAN (193-1995). http://www.fao.org/fileadmin/user_upload/livestockgov/.../CXS_193s. pdf Date consulted: April 20, 2015.

Galadima A, Garba ZN, Leke L, Almustapha MN, Adam IK (2011) Domestic water pollution among local communities in Nigeria. Causes and consequences. European Journal of Scientific Research 52: 592603.

García ME (1973) Apuntes de climatología. Universidad Autónoma de México. México. 71p.

García SJ, Guzmán SE, Fortis HM (2006) Demanda y distribución del agua en la Comarca Lagunera, México. Agrociencia 40: 269-276.

Hüvely A, Buzás I, Borsné J, Tóthné Z (2011) Examination of the arsenic accumulating capacity of lettuce growing in aggregate hydroponics under the influence of arsenic polluted nutrient solution. Agriculture and Environment 3: 122-131.

IMTA (2012) FAO: Sequías recurrentes obligan a una mejor gestión de los recursos hídricos. http://www.imta. gob.mx > Inicio > Noticias / Eventos > Internacionales. Date consulted: April 14, 2015.

Mancilla V, Ortega EMV, Ramírez AH, Uscanga MMR, Ramos BRE, Reyes OAL (2012) Metales pesados totales y arsénico en el agua para riego de Puebla y Veracruz, México. Revista Internacional de Contaminación Ambiental 28: 39-48.

SE (2001) NMX-AA-051-SCFI-2001: Análisis de agua - determinación de metales por absorción atómica en aguas naturales, potables, residuales y residuales tratadas-método de prueba. http://www.conagua.gob. mx/CONAGUA07/.../NMX-AA-051-SCFI-2001.pdf. Date consulted: April 30, 2013.

SS (1994) NOM-117-SSA1-1994: Bienes y servicios. Método de prueba para la determinación de cadmio, arsénico, plomo, estaño, cobre, fierro, zinc y mercurio en alimentos, agua potable y agua purificada por espectrometría de absorción atómica. http://www.salud.gob.mx/unidades/cdi/nom/117ssa14.html. Date consulted: April 12, 2015.

Pedroza SA, Flores RJL, Torres MM, Cantú BJE, Piceno SC, Yáñez ChLG (2014) Eficiencia del agua de riego en la producción de maíz forrajero (Zea mays L.) y alfalfa (Medicago sativa): Impacto social y económico. Revista Terra Latinoamericana 32: 231-239. 
Pérez-León JM (2011) Manual para determinar la calidad del agua para riego agricola. Veracruz, México. Universidad Veracruzana - Facultad de Ciencias Agrícolas. Xalapa de Enríquez, Veracruz, México, 41p.

Sarabia MIF, Cisneros AR, Aceves de Alba J, Durán GHM, Castro LJ (2011) Calidad del agua de riego en suelos agrícolas y cultivos del Valle de San Luis Potosí, México. Revista internacional de contaminación ambiental 27: 103-113.

Sardiñas PO, Rubalcaba SCh, Fernández-Novo M, Hernández Y, Pérez A (2006) Evaluación físico-química y microbiológica del agua de la presa El Cacao (Cotorro, Cuba). Higia Sanidad Ambiental 6: 202-206.

Sandeep G, Sangita A, Sandeep K, Rakhi R, Dinesh K (2012) Biological effect of heavy metal in drinking water samples of Western Uttar Pradesh region in India. Journal of Applied Pharmaceutical Science 2: 177-181.

SCFI (2006) Norma Mexicana NMX-AA-132-SCFI-2006. Muestreo de suelos para la identificación y la cuantificación de metales y metaloides, y manejo de la muestra. Secretaría de Comercio y Fomento Industrial. Diario oficial de la Federación. Fecha de consulta 5 de septiembre de 2006. http://www.biblioteca.semarnat.gob.mx/janium/Documentos/Ciga/agenda/PPD02/NMX132AA2006. pdf. Date consulted: May 17, 2013.

SEMARNAT (2007) Norma Oficial Mexicana NOM-147-SEMARNAT-2004. Diario Oficial de la Federación. 2 de marzo de 2007. www.profepa.gob.mx/.../file/.../nom-147-semarnat_ssa1-2004.pdf. Date consulted: April 14, 2015.

ONU (2012) Programa mundial de evaluación de los recursos hídricos (WWAP). http://www.un.org/spanish/ waterforlifedecade/food_security.shtml. Date consulted: June 19, 2016. 
